\title{
APPLICATION OF GIS IN QUANTITATIVE GEOMORPHOLOGICAL ANALYSIS OF THE UNA RIVER BASIN (BOSNIA AND HERZEGOVINA)
}

\author{
Aida Korjenić, PhD., Amina Sivac, M.A., Amra Banda, M.A. \\ Department of Geography, Faculty of Science, University of Sarajevo \\ Zmaja od Bosne 33-35, BIH-7I 000 Sarajevo, Bosnia and Herzegovina \\ e-mail: aida.k@pmf.unsa.ba, amina.sivac@pmf.unsa.ba, amra.banda@pmf.unsa.ba

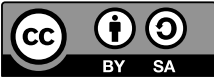

Original scientific article

COBISS 1.01

DOI: $10.4312 /$ dela.48.2.77-94

\begin{abstract}
In this paper, the morphometric characteristics of the Una River basin (Bosnia and Herzegovina) were analyzed using geographic information systems (GIS). Quantitative geomorphological analysis was carried out (hypsometric characteristics, slope inclination,vertical relief dissection, and slope exposition). Analyzed parameters are indicators of shapes and recent processes in relief. The significance of this analysis is reflected in the fact that the obtained data have numerical value, are verifiable and multiple applicable in practice for the purposes of agriculture water management, construction sector urbanism, tourism, spatial planning, etc.
\end{abstract}

Keywords: GIS, geomorphology, morphometry, karstology, Una River basin, Bosnia and Hezregovina

\section{UPORABA GEOGRAFSKEGA INFORMACIJSKEGA SISTEMAV KVANTITATIVNI GEOMORFOLOŠKI ANALIZI POREČJA UNE (BOSNA IN HERCEGOVINA)}

\section{Izvleček}

V prispevku smo s pomočjo geografskih informacijskih sistemov (GIS-ov), kartografskih in matematično-statističnih metod analizirali morfometrične značilnosti porečja Une. Kvantitativna geomorfološka analiza je vključevala hipsometrične značilnosti, naklone, vertikalno razčlenjenost reliefa in ekspozicije reliefa v porečju Une. Analizirani parametri so indikatorji reliefnih oblik in sodobnih procesov preoblikovanja reliefa. Pridobljeni podatki imajo numerično in praktično vrednost, na primer za potrebe kmetijstva, upravljanja voda, gradbeništva, urbanizma, turizma, prostorskega načrtovanja itd.

Ključne besede: GIS, geomorfologija, morfometrija, krasoslovje, porečje Une, Bosna in Hercegovina 


\section{INTRODUCTION}

A major emphasis in geomorphology over the past several decades has been on the development of quantitative physiographic methods to describe the evolution and behavior of surface drainage networks (Horton, 1945; Dobos et al., 2010). An application of Geographic information system (GIS) in geomorphological studies started in the 1990s, almost 100 years after the first geomorphographical relief analysis of Penck (1894). The GIS has proven its advantages in all areas where spatial data visualization and manipulation of large numbers of data are required. GIS technology can be used for scientific research, resource management, asset management, development and spatial planning, cartography, and infrastructure planning.

A large number of pioneer scientific papers focusing on GIS application in geomorphology had their focal point on digitally derived classification of landform, especially DEMs and their advantages (Dikau et al., 1991; Moore et al., 1991; Pike, 1995; Terrain analysis ..., 2000). Rao (2002) states the usage of GIS technology for geomorphological studies has increased its importance due to connection with scientific disciplines, such as geology, geomorphology and hydrology. According to Pareta and Pareta (2012), GIS techniques are used for assessing various terrain and morphometric parameters of the drainage basins, as they provide tool for the analysis of spatial information. GIS technology is ideal for geomorphological analysis since terrain does control movement and accumulation of surface and groundwater (Shrivastava, Bhattacharya, 2000; Pareta, Pareta, 2012).

Quantitative geomorphological analysis implies the representation of morphological processes, shapes and reliefs in general using numerical parameters, and it is important to emphasize that their number is virtually unlimited (Marković, 2003). The primary feature of such an analysis is that its data is dimensioned and that, therefore, it is verifiable and has multiple applicability in practice. Analysis of geomorphological features implies studying the indeterminacy, structure and dynamics of the relief, its genesis and its evolution.

The results of the quantitative analysis of the relief of the Una River basin are presented in tabular and on thematic geomorphological maps. Analyzed parameters are expression of morphostructural and morphogenetic relief characteristics, and they serve as indicators of shapes and recent processes in relief. The results obtained by the quantitative geomorphological analysis in the Una River basin have a wide applicative value and they are unavoidable in the procedure of determining the intensity of erosive processes, protection and improvement of spatial and living environment.

\section{METHODS}

Our survey on the geomorphological characteristics of the Una River basin was based on geomorphological mapping method which used a combination of various approaches to desktop research and data analysis. For an application of GIS in quantitative geomorphological analysis, we relied on primary sources, particularly on certain contributions 
to scientific and professional journals and anthologies, such as Geografski pregled (Geographical Review), Acta geographica Bosniae et Herzegovinae, and others.

There was a very extensive data preparation phase (literature, maps, data collection). Geomorphological analysis was conducted by applying analytic geomorphological methods (Pavlopoulos, Evelpidou, Vassilopoulos, 2009), the following were applied: analysis of hypsometric relations, slope analysis, analysis of the vertical relief dissection and analysis of expositions. Using the topographic maps (in scales of 1:25,000 and 1:50,000), a morphographic analysis was carried out. The analysis is based on the processing of the digital terrain model (DTM) using GIS technology. Using different GIS methods, raster and vector values have been obtained for the above mentioned four parameters. They are evaluated according to their geographical distribution, frequency and domination. The obtained results give an overview of the geomorphometric characteristics of the Una River basin, for each parameter individually.

Field work was based on locating and taking photographs of the most significant relief forms determined by reviewing literature and maps, respectively on the recognition and definition of dominant structures and processes. Morphographic mapping within the fieldwork is completed with morphometric data analysis in ArcGis.

\section{BASIC GEOMORPHOLOGICAL CHARACTERISTICS OF THE UNA RIVER BASIN}

The Una River basin extends mostly on the territory of Bosnia and Herzegovina, while the smaller area covers a part of the neighboring Republic of Croatia. In Bosnia and Herzegovina, these are mostly northwestern parts, and smaller areas in the north and west, while in Croatia the morphostructures include Mala Kapela, Plješevica and Zrinjska Gora (Korjenić, 2014).

From the broader geomorphological view (Bognar, 1999), the Una River basin is a part of the mega-geomorphological regions of the Dinaric and Pannonian Basin system. These two mega-units are a part of the Alpine-Himalayan mountain belt. Independent geomorphological ensembles in this area are mountainous structures or mountainous ridge and massif, and mountainous groups of fold-overthrust-fault geological structures of the Dinaric system.

The morphogenesis of the subgeomorphological regions of independent assimilation has been significantly influenced by the neotectonic development of adjacent mountain elevations. They are associated with the dissected pediments of hill-plateau morphological features and smaller basins and river valleys as micromorphological units. Pediments are represented by the level of the flattening and the gentle slopes at the foot and on the sides of the mountain elevations, while the valleys mostly coincide with the syncline and potolin structures. By analyzing all structural-facial parameters in the global geotectonic structure of the territory of Bosnia and Herzegovina and in the Una River basin, three zones are distinguished: the area of the Outer Dinarides, which mostly belongs to the High karst overthrust; the area of the Central Dinarides, which corresponds to the belt of 
Figure 1: Geographic position of the Una River basin. Slika 1: Geografski položaj porečja Une.

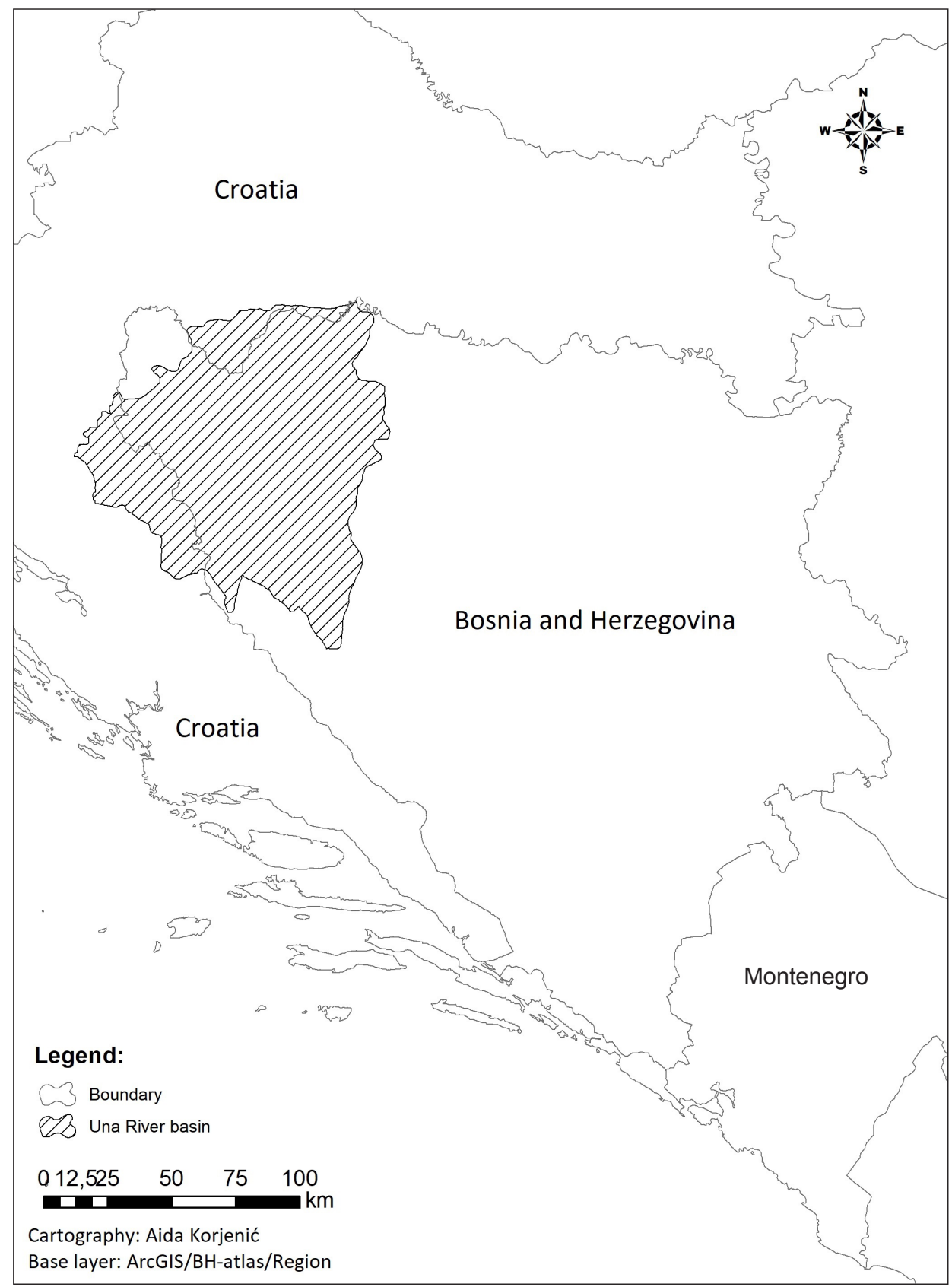


Paleozoic shrubs, Mesozoic limestone and flysch; the area of the Inner Dinarides which borders the previous zone with the head of the Durmitor Cover (Čičić, 2002).

\section{RESULTS AND DISCUSSION}

Analyses of the river system and morphometric indicators were obtained by working in the ArcGIS program, from the topographic maps (scale 1:25,000). Considering all the constant and major intermittent river flows, the length of the watercourse in the Una River basin, which is $10,190.6 \mathrm{~km}$, was obtained. The length of intermittent flows is $6,012.8$ $\mathrm{km}$, and the length of the constant river flows is $4,177.8 \mathrm{~km}$. Measurement of artificial canals (total length of $34.2 \mathrm{~km}$ ) was performed, referring to the Gomjenica River and Gornji Obodni Kanal.

\section{I Hypsometric characteristics of Una River basin}

The elevations in the Una River basin are reduced from the south to the north. The average height of the Una River basin is $598.98 \mathrm{~m}$, and the depth of basin is incising to $376.18 \mathrm{~m}$. When we analyzed the altitude of the larger basins of Una River tributaries (Sana and Unac rivers) and immediate catchment of Una River, we were able to notice certain differences. Unac River has the largest average height of the basin at $933.5 \mathrm{~m}$, which is about $387 \mathrm{~m}$ higher than the average Una River height (546.03 m). The Sana River basin is also somewhat higher with $587.1 \mathrm{~m}$. According to this data, Unac River as a typical mountain river, forms the highest part of the Una River basin.

Figure 2: The distribution of hypsometric levels in the Una River basin.

Slika 2: Višinska pasovitost v porečju Une.

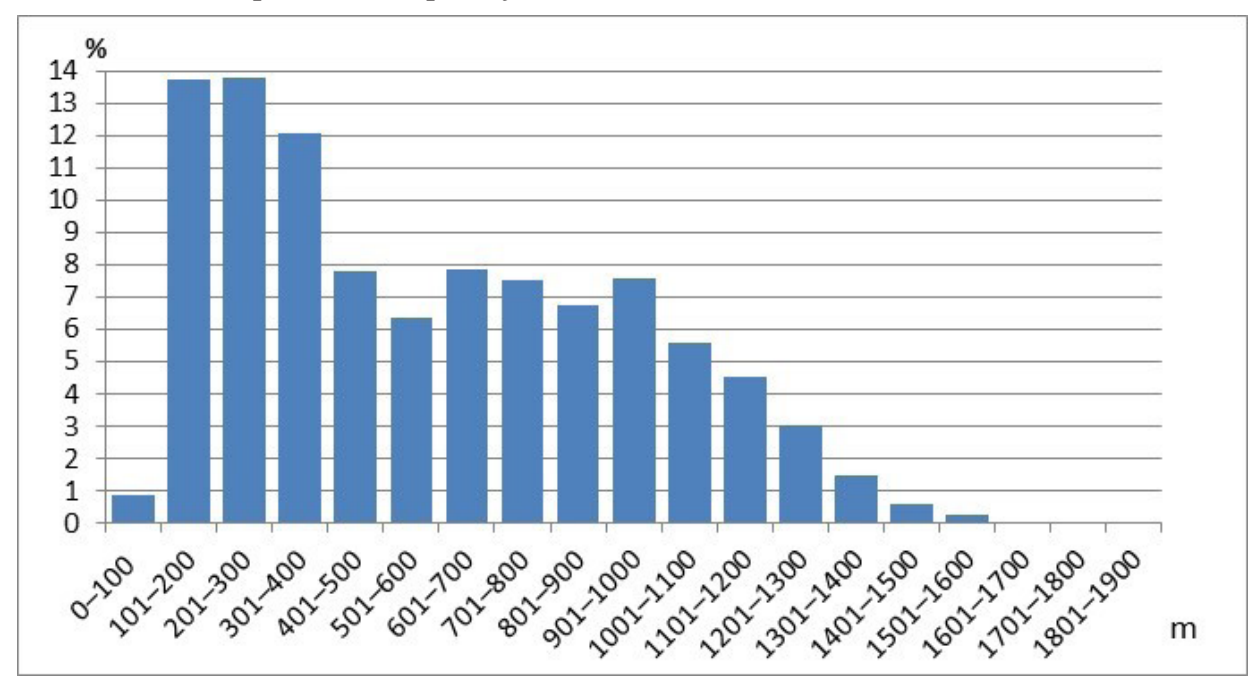

Source/Vir: Own survey. 
The average altitude in the Una River basin is mostly affected by the lower part of the basin, which greatly reduces it. The average height of this part of the basin is $236 \mathrm{~m}$. By analyzing topographic maps in the ArcGIS program, 20 levels per $100 \mathrm{~m}$ above sea level were identified in the Una River basin. The highest levels include peaks of Klekovača Mountain $(1961 \mathrm{~m})$, while the lowest include the mouth of the Una and Sava rivers on the elevation of $92 \mathrm{~m}$.

Una River basin has predominantly hilly-mountainous character. Hypsometric level of $201-300 \mathrm{~m}$ has the biggest spatial coverage $\left(1,374.31 \mathrm{~km}^{2}\right)$, followed by a level of $101-200 \mathrm{~m}$ with $1,373.31 \mathrm{~km}^{2}$ and $301-400 \mathrm{~m}$ (with an area of $1,207.63 \mathrm{~km}^{2}$ ). Levels of 401 to $1400 \mathrm{~m}$ cover the area of $5,844.54 \mathrm{~km}^{2}$. All these levels of 101 to $1400 \mathrm{~m}$ a.s.l. make up $98.19 \%$ of the total basin. The smallest area is covered by the levels of $1701-1800 \mathrm{~m}$ and above, with a total of about $3 \mathrm{~km}^{2}$.

The surface of the Una River basin in the flattened areas, the hills and the mountains can also be determined on the basis of the hypsographic curve of the basin, which shows the distribution of the basin relief by the hypsometric levels (Figure 3).

Figure 3: Hypsographic curve of the Una River basin.

Slika 3: Hipsografska krivulja porečja Une.

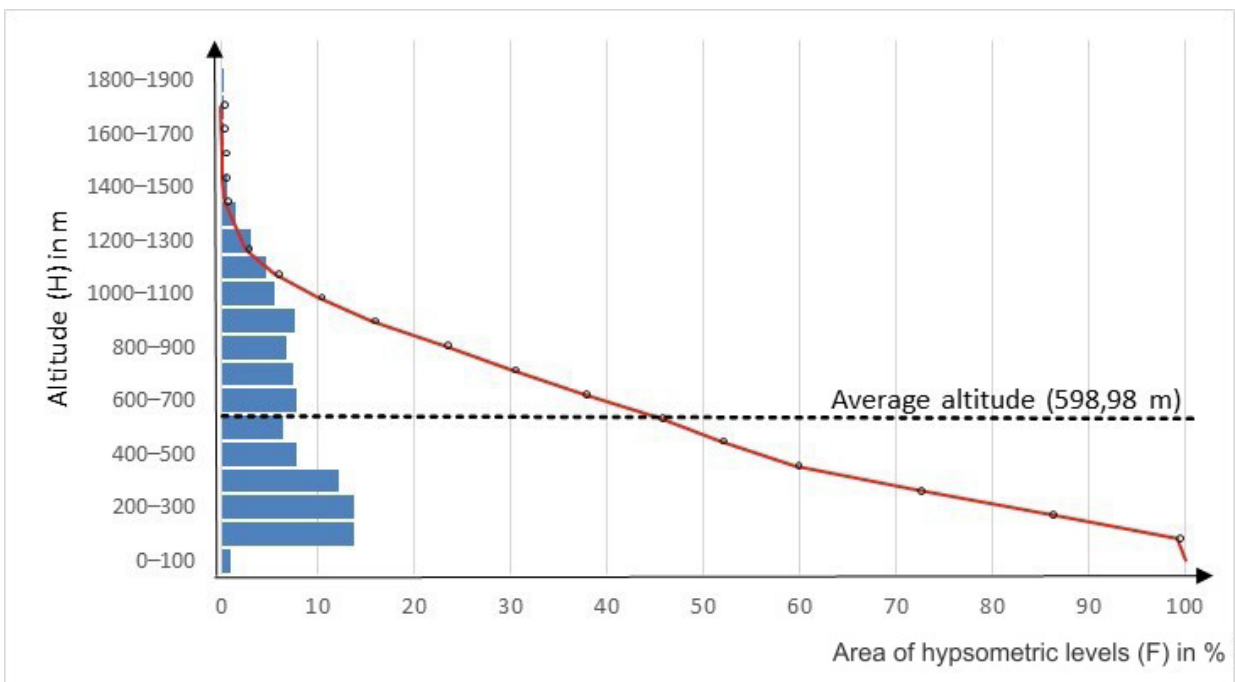

Source/Vir: Own survey.

The hypsometric levels were analysed as geomorphologic categories. The lowest, flattened hypsometrical levels include $1,157.73 \mathrm{~km}^{2}$ of the total area of Una River basin. Slightly rippled and hillside relief participates with $36.23 \%$ in total area. When it comes to the area of more than $501 \mathrm{~m}$ above sea level which refers to pediment stairs and mountainous split structures, this area covers $52.17 \%$ of the basin area. Structures of 501 to $1000 \mathrm{~m}$ above sea level have the largest share of the total area $\left(3,632.88 \mathrm{~km}^{2}\right)$. 
Figure 4: Hypsometric map of the Una River basin. Slika 4: Karta višinskih pasov porečja Une.

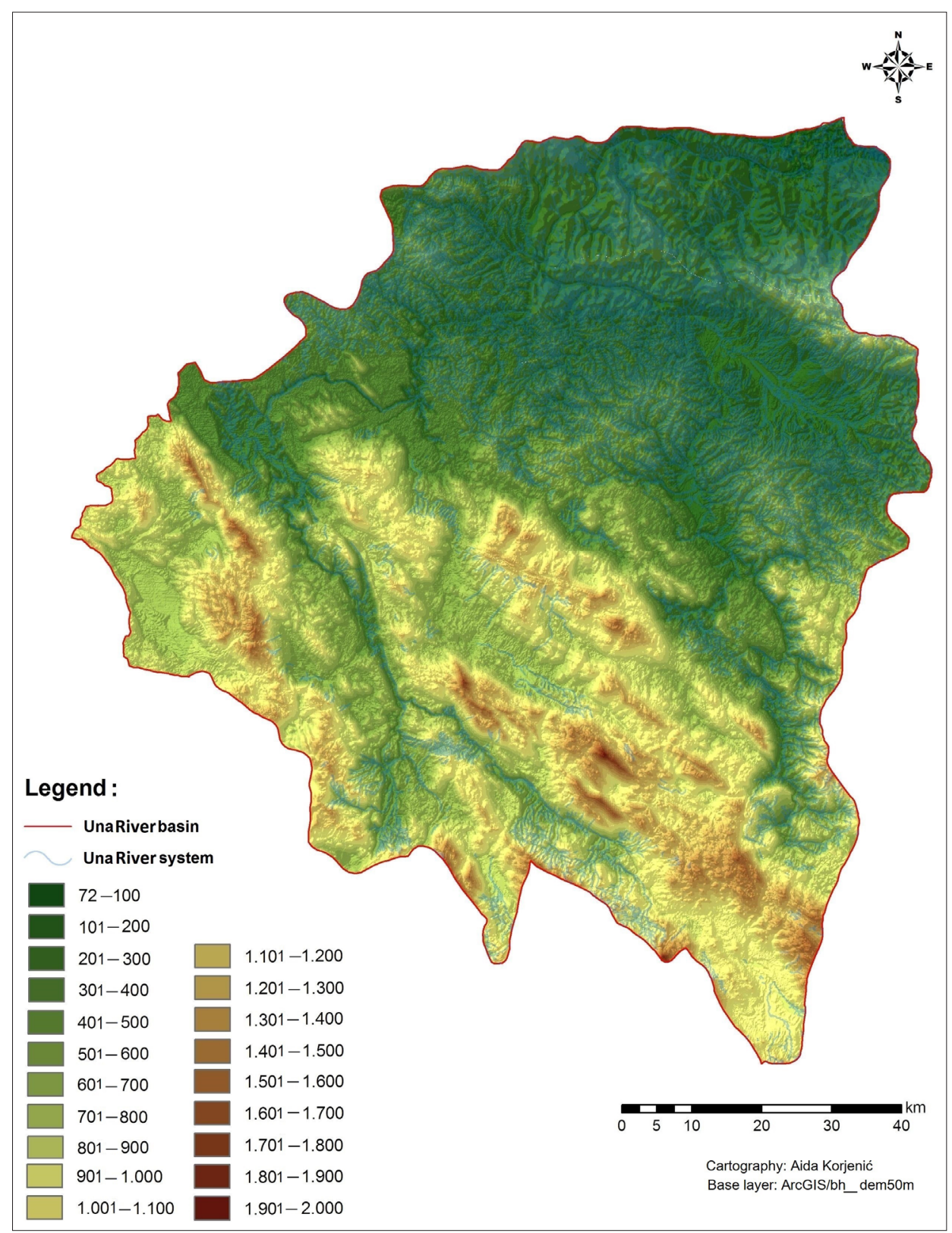


Morphostructural relief factors which are distinguished in the Sana River basin are also noticed in the Una River basin: mountain morphostructures, pediments, hills, basins, karst plateaus and river aluviums (Temimović, 2014).

The hypsometric map points to the dominant northwest-southeast direction of relief stretching, which follows the Dinaric structure. The lactonic swirling of river valleys and the alteration of the aforementioned course was conditioned by subsequent tectonic movements, as lithologic substrate that improved cutting of the river bed.

\subsection{Slope inclination of Una River basin}

For the purposes of this study, analysis of slope inclination was performed in the program ArcGIS, using the IGU classification (Marković, 2003). The largest area of 3,392.03 $\mathrm{km}^{2}$ includes the flattened surfaces with the slope inclination up to $2^{\circ}$, followed by the surfaces with the slope inclination of $6-15^{\circ}$ which cover $3,341.14 \mathrm{~km}^{2}$ of an area. These two slope inclination categories occupy $67.47 \%$ of the total area of the Una River basin. The slope category with inclination $55^{\circ}$ and more covers only $0.1 \mathrm{~km}^{2}$ of the basin. It is noted that a considerable area in the Una River basin, around $2,005.00 \mathrm{~km}^{2}$, includes the surface with the visible emergence of the masses movement, wherein washing, flowing and sliding of the ground was observed $\left(3-5^{\circ}\right)$. The higher slope inclination categories appear in the area of intense fluvial erosion, river canyons and mountain peaks, while the smallest slope inclination categories appear in karst fields and valleys as well as alluvial flats and river terraces. The spatial distribution of the mentioned slope inclination categories in the Una River basin has certain specifics.

Table 1: The distribution of the slope inclination categories in the Una River basin. Preglednica 1:Naklonski razredi v porečju Une.

\begin{tabular}{|l|c|c|c|c|c|c|}
\hline $\begin{array}{l}\text { Slope inclination category } \\
\text { (in }{ }^{\circ} \text { ) }\end{array}$ & $\mathbf{0}^{\circ}-\mathbf{2}^{\circ}$ & $\mathbf{3}^{\circ}-\mathbf{5}^{\circ}$ & $\mathbf{6}^{\circ}-\mathbf{1 5}^{\circ}$ & $\mathbf{1 6}^{\circ}-\mathbf{3 5}^{\circ}$ & $\mathbf{3 3}^{\circ}-\mathbf{5 5}$ & $>\mathbf{5 5}^{\circ}$ \\
\hline $\begin{array}{l}\text { Share of the territory } \\
\text { (in \%) }\end{array}$ & 33.99 & 20.09 & 33.48 & 12.13 & 0.31 & 0.00 \\
\hline
\end{tabular}

Source/Vir:Own survey.

The largest homogeneous surfaces of the same slope inclination category are in the first category, i.e. this is a terrain with a gradient of 0 to $2^{\circ}$, mainly linked to the ravinevalley areas of Sana and Gomjenica rivers, parts of the Una-Koranian Plateau, Krbavsko, Petrovaćko and Glamoćko karst polje and in the river mouth of the Una and the Sava rivers. These areas are morphogenetically different, on one side with developed fluvial processes, while on the other there are terrains with the expressed karst processes. Narrow zones of the $3^{\circ}-5^{\circ}$ slope inclination category are mostly noticeable in the area of UnaKoranian Plateau and other major karst morphostructures. Slopes of the latter category in this area are probably remains of karsted fossil valleys and gorges (Bočić, 2010). The slopes of the $5^{\text {th }}$ and $6^{\text {th }}$ category $\left(33^{\circ}-55^{\circ}\right.$ and $\left.>55^{\circ}\right)$ can be observed in several major 
areas, namely slopes of elevations and depressions, indicating the structural predisposition of the origin and the Dinaric direction of stretching. All other areas have a mosaicmesh structure (Table 2).

Table 2: Distribution of slope inclination categories (in \% of the area) according to hypsometric levels in the Una River basin.

Preglednica 2:Naklonski razredi (delež območja v\%) po višinskih pasovih v porečju Une.

\begin{tabular}{|c|c|c|c|c|c|c|}
\hline \multirow{2}{*}{$\begin{array}{l}\text { Hypsometric level } \\
\text { (in m) }\end{array}$} & \multicolumn{6}{|c|}{ Slope inclination category } \\
\hline & $0^{\circ}-2^{\circ}$ & $3^{\circ}-5^{\circ}$ & $6^{\circ}-15^{\circ}$ & $16^{\circ}-35^{\circ}$ & $33^{\circ}-55^{\circ}$ & $>\mathbf{5 5 ^ { \circ }}$ \\
\hline $0-100$ & 87.12 & 10.96 & 1.90 & 0.02 & & \\
\hline $101-200$ & 66.75 & 20.70 & 11.26 & 1.24 & 0.05 & \\
\hline $201-300$ & 43.61 & 23.52 & 28.13 & 4.66 & 0.08 & \\
\hline $301-400$ & 41.70 & 20.74 & 29.40 & 8.01 & 0.15 & \\
\hline $401-500$ & 30.44 & 20.29 & 35.56 & 13.34 & 0.37 & \\
\hline $501-600$ & 28.44 & 21.28 & 35.37 & 14.44 & 0.47 & \\
\hline $601-700$ & 34.05 & 21.35 & 31.52 & 12.65 & 0.43 & \\
\hline $701-800$ & 18.61 & 23.84 & 41.40 & 15.67 & 0.48 & \\
\hline $801-900$ & 17.60 & 19.08 & 45.70 & 17.34 & 0.28 & \\
\hline $901-1000$ & 24.65 & 16.42 & 41.83 & 16.8 & 0.29 & 0.01 \\
\hline $1001-1100$ & 16.75 & 14.13 & 48.45 & 20.36 & 0.31 & \\
\hline $1101-1200$ & 15.93 & 15.41 & 45.64 & 22.37 & 0.65 & \\
\hline $1201-1300$ & 17.60 & 13.30 & 43.98 & 24.35 & 0.77 & \\
\hline $1301-1400$ & 18.15 & 10.37 & 43.94 & 26.59 & 0.95 & \\
\hline $1401-1500$ & 19.10 & 10.57 & 38.98 & 30.02 & 1.29 & 0.04 \\
\hline $1501-1600$ & 10.19 & 10.21 & 35.61 & 42.45 & 1.54 & \\
\hline $1601-1700$ & 4.13 & 3.85 & 21.72 & 66.83 & 3.47 & \\
\hline $1701-1800$ & 6.40 & 4.08 & 11.70 & 70.53 & 7.29 & \\
\hline $1801-1900$ & & & 12.24 & 74.49 & 13.27 & \\
\hline $1901-2000$ & & & 8.07 & 67.74 & 24.19 & \\
\hline
\end{tabular}

Source/Vir: Own survey.

The average slope of the entire area is $6.57^{\circ}$ and it indicates the presence of small hills, hills and flat terrain in the macro-plan, while the mosaic-mesh structure alternating from the $1^{\text {st }}$ to the $6^{\text {th }}$ slope inclination category emphasizes the expressed micro-diversity of the spatial coverage in the basin, primarily as a result of the karstification process, but also as a result of neotectonic movements that are reflected in relief. 
Figure 5: Map of slope inclination in the Una River basin. Slika 5: Karta naklonskih razredov v porečju Une.

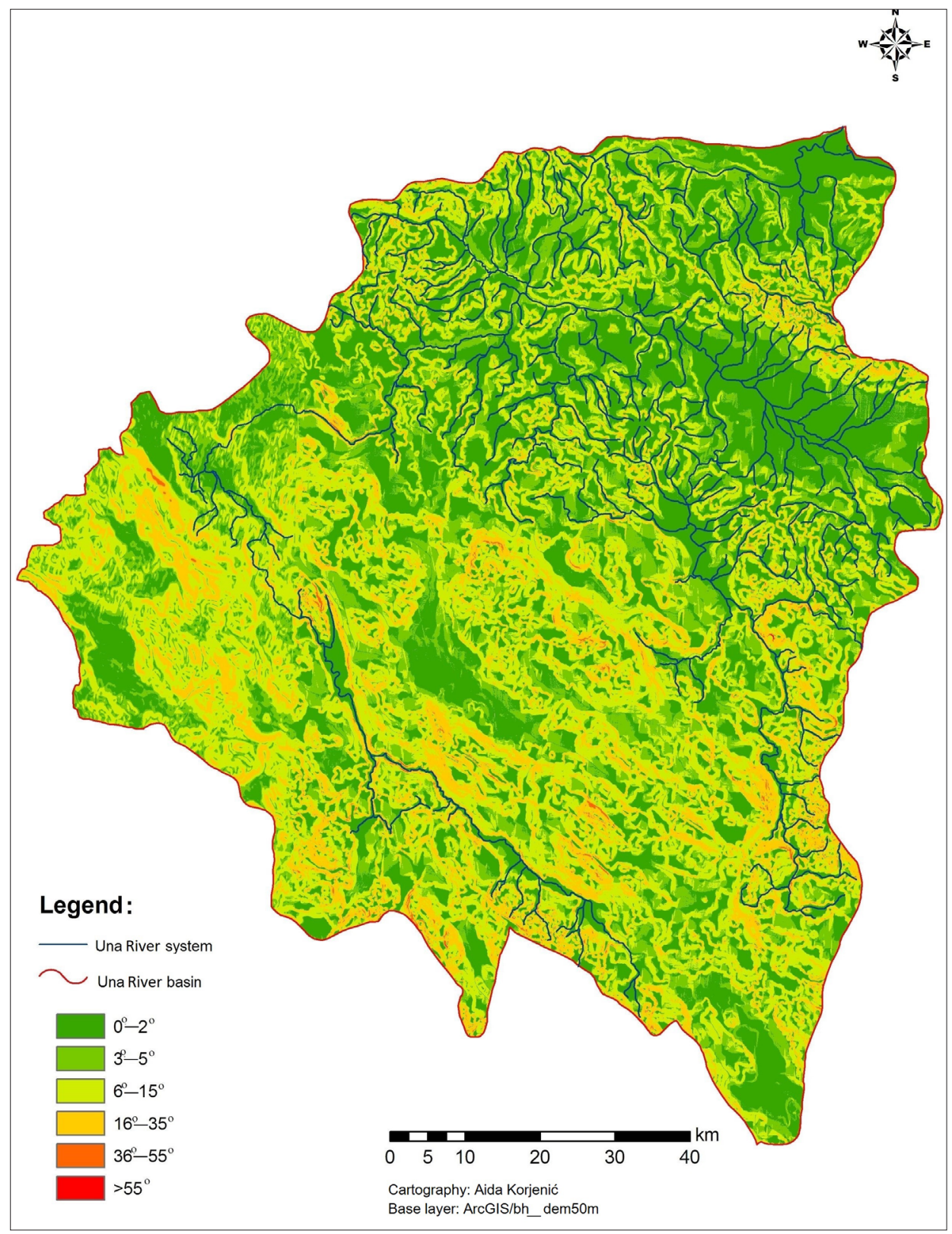




\subsection{Relief energy of Una River basin}

Relief energy represents parameter of vertical relief dissection. Higher vertical dissection has larger relief energy and vice versa, smaller vertical dissection has a smaller energy. Relief energy represents a parameter of exogenous processes' development intensity, and it is conditioned mainly by petrographic composition and water quantity in that area. Areas with larger relief energy have stronger erosion, while terrains with smaller energy represent area with expressed accumulation, which can affect on the causing of floods in the river basin. Because of the various combinations of hydrogeographic factors underpinning runoff (such as land cover, soil, bedrock, and relief) in water basin areas of watercourses, individual types of floods generally occur in certain areas only (Trobec, 2016). Concerning that horizontal distance on which the altitude difference is constantly measured, this parameter most often is proportional to inclination. When analyzing precipitations runoff into the flow from the basin area, relief energy is very important as well as slope inclination.

Figure 6: Canyon of Una River and Rmanj Valley - A, Una-Korana Plain - B (Photo: A. Korjenić, 2014).

Slika 6: Kanjon reke Une in dolina Rmanj-A, Unsko-koranska uravnava - B (foto: A. Korjenić, 2014).

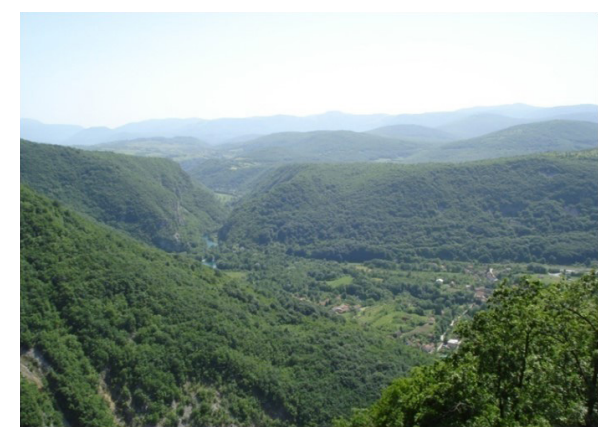

A

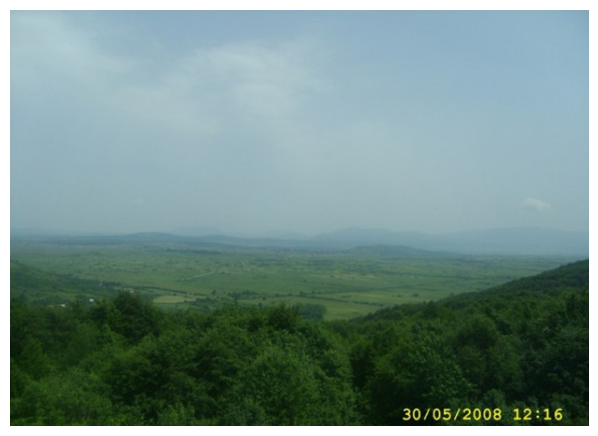

$B$

Vertical dissection is determined as the altitude difference between the highest and lowest points in $5 \mathrm{~km}$ length, means as altitude difference within the unit area dimensions $5 \times 5 \mathrm{~km}$ (Gams, 1981). According to this, relief can be classified by dissection into several classes (Marković, 2003). For the Una River basin analysis (based on the usage of the ArcGIS program), 5 relief classes have been sampled as well as their distribution according to hypsometric levels. This classification may have orientation character and it is adjusted for the needs of this paper. Selection of vertical dissection classes and their span's size is determined according to characteristics of the mapped area. In flat terrains the span decreases, and in mountain-hill ones, increases. For the Una River basin, in order to gain clear picture, vertical dissection has been determined as the altitude difference in smaller unit area, dimensions $1 \mathrm{x} 1 \mathrm{~km}$, and then seven relief energy classes have been sampled (Table 3, Figure 7). 
Table 3: Classes of vertical relief dissection in the Una River basin. Preglednica 3: Razredi reliefne energije v porečju Une.

\begin{tabular}{|l|c|c|}
\hline Classes of vertical relief dissection & Height difference (m) & Size (in $\mathbf{k m}^{\mathbf{2}}$ ) \\
\hline Flat areas and poorly flattened plains & $0-59$ & $1,844.38$ \\
\hline Poorly dissected reliefs & $59.1-110$ & $2,161.76$ \\
\hline Poorly to moderately dissected relief & $110.1-158$ & $1,983.11$ \\
\hline Moderately dissected relief & $158.1-209$ & $1,697.67$ \\
\hline Moderately to extremely dissected relief & $209.1-347$ & $1,811.44$ \\
\hline Extremely dissected relief & $347.1-455$ & 375.26 \\
\hline Extremely to very dissected relief & $455.1-733$ & 106.79 \\
\hline
\end{tabular}

Source/Vir: Own survey.

Figure 7: Map of the relief energy in the Una River basin.

Slika 7: Karta reliefne energije v porečju Une.

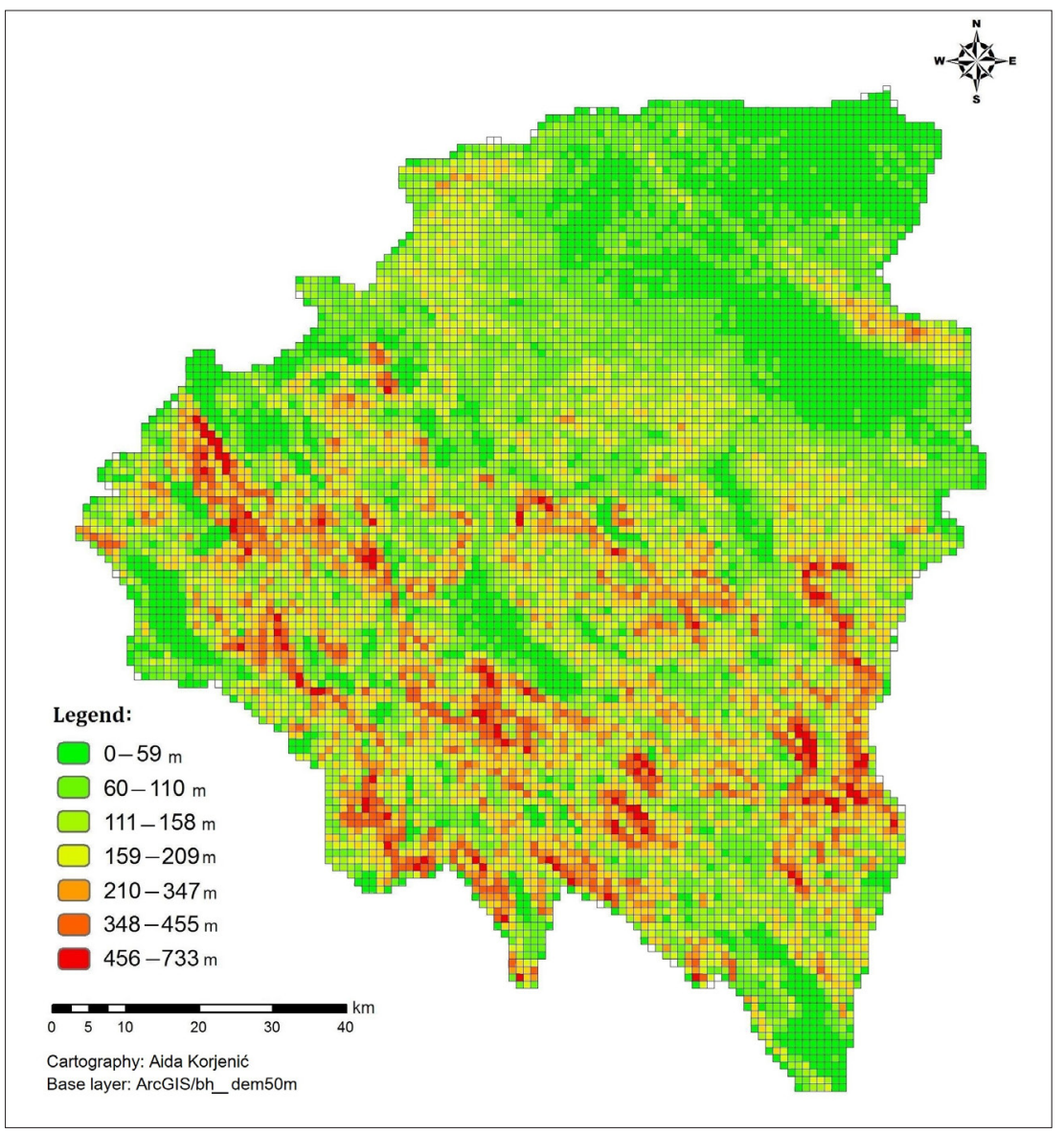


For the analyzed area, one can conclude that it has mainly poorly and poorly to moderately dissected relief. Flat areas and poorly dissected reliefs in general, cover $40.14 \%$ of the total Una River basin. Some larger percentage of the spatial coverage, 55.03\%, belongs to moderately dissected relief, while extremely dissected relief spreads on only $4.8 \%$ territory of the Una River basin. Flat and poorly flat dissected parts suit to river alluvions, basins and plateaus in karst, with slope inclination up to $6^{\circ}$.

Poorly and poorly to moderately dissected relief are made of foothills in the basin with slope inclination from $7^{\circ}$ to $14^{\circ}$, while moderately and moderately to extremely dissected relief is presented with pre-mountainsteps with slope inclination from $15^{\circ}$ to $22^{\circ}$. Orthographic structures with mountain peaks, as the highest morphostructure relief basin's elements, mostly have slope inclination higher than $22^{\circ}$, and it is characterized by extremely and extremely to very dissected relief.

\subsection{Slope exposition of Una River basin}

Areas with northeast expositions (NE) cover the largest part of the basin area $\left(1,527.3 \mathrm{~km}^{2}\right)$, followed by an area with southwest (SW) expositions of $1,365.4 \mathrm{~km}^{2}$. Majority of mountain morphostructures as well as parts of river valleys have Dinaric stretching direction, i.e. northwest-southeast direction, so the above mentioned expositions are the most presented ones. Total area of northwest and southeast expositions amounts to $29.07 \%$ of the Una River basin. Flat parts cover $12.41 \%$ of total area (slope inclination from 0 to $5^{\circ}$ ), which comprehends to the fields, plateaus, ravines and alluvial plateaus and river terraces. Northern expositions $(\mathrm{N})$ as well, cover the significant area, that is $10.78 \%$ of the total surface area.Two values for northern expositions were stated (as $\mathrm{N}^{1}$ and $\mathrm{N}^{2}$ in Table 4). The reason for that is the employment of the ArcGIS program which counts the northern exposition on east and west from zero azimuth, that is from $337.5^{\circ}$ to $22.5^{\circ}$. Eastern and western expositions have nearly the same area in span of about 1080 to $1120 \mathrm{~km}^{2}$. Though the smallest one, south (S), in comparison to southeast (SE) and northwest (NW) expositions, cover some larger area. Participation of these expositions in percentage is almost equal, and their total area in the Una River basin amounts $2526.2 \mathrm{~km}^{2}$.

The structure of vertical exposition arrangements was done according to hypsometric levels of 100 m (Spahić, 2002; Sretenović, 1971). According to this, northern expositions in the Una River basin would cover 4,569.3 $\mathrm{km}^{2}$, while south expositions would take a bit smaller area, $4,127.9 \mathrm{~km}^{2}$ (relation $52.5: 47.5 \%$ ). A part of the area of $1,282.6 \mathrm{~km}^{2}$ refers to flat areas. In all hypsometric levels there is a domination of north expositions, and that is to $200 \mathrm{~m}$ altitude with approximately $5 \%$ of the total Una River basin, in the zone from 201 to $500 \mathrm{~m}$ they participate with $14.9 \%$, while in mountain area (above 500 $\mathrm{m})$ they cover $25.1 \%$ area. Northeast (NE) exposition has the largest surface $(15.3 \%)$, especially in level $501-1000 \mathrm{~m}, 41.8 \%$ of total northeast expositions in all altitudinal zones. Southwest (SW) exposition, of the south ones, has the greatest part, with $13.7 \%$ of total basin area. 
Table 4: Slope exposition according to hypsometric levels (in $\left.\mathrm{km}^{2}\right)$.

Preglednica 4: Ekspozicija pobočij po višinskih pasovih $\left(\mathrm{v} \mathrm{km}^{2}\right)$.

\begin{tabular}{|c|c|c|c|c|c|c|c|c|c|c|}
\hline \multirow{2}{*}{$\begin{array}{c}\text { Hypsometric } \\
\text { level }\end{array}$} & \multicolumn{10}{|c|}{ Slope exposition } \\
\hline & Flat & $\mathbf{N}^{1}$ & NE & $\mathbf{E}$ & SE & $\mathbf{S}$ & SW & W & NW & $\mathbf{N}^{2}$ \\
\hline $0-100$ & 64.063 & 6.7467 & 8.2922 & 2.8914 & 0.5904 & 0.5818 & 0.0955 & 0.2084 & 1.8582 & 1.5022 \\
\hline $101-200$ & 357.33 & 94.48 & 186.77 & 149.00 & 107.53 & 103.27 & 136.78 & 103.68 & 91.87 & 42.57 \\
\hline $201-300$ & 247.51 & 77.51 & 166.43 & 149.11 & 124.79 & 135.37 & 148.84 & 142.52 & 131.52 & 50.71 \\
\hline $301-400$ & 174.74 & 78.38 & 170.76 & 132.48 & 109.17 & 112.55 & 131.75 & 131.87 & 116.54 & 49.39 \\
\hline $401-500$ & 94.71 & 53.22 & 123.39 & 93.23 & 59.47 & 69.39 & 89.17 & 88.85 & 77.91 & 32.12 \\
\hline $501-600$ & 61.35 & 48.55 & 113.51 & 77.45 & 42.33 & 49.56 & 71.36 & 74.91 & 62.74 & 32.00 \\
\hline $601-700$ & 53.96 & 61.19 & 133.06 & 95.98 & 54.51 & 64.33 & 124.42 & 96.30 & 68.34 & 33.38 \\
\hline $701-800$ & 32.30 & 55.24 & 139.79 & 94.89 & 53.22 & 65.58 & 127.27 & 90.92 & 55.84 & 34.48 \\
\hline $801-900$ & 37.31 & 48.58 & 118.27 & 77.39 & 51.95 & 68.88 & 106.06 & 81.64 & 56.13 & 28.47 \\
\hline 901-1000 & 72.23 & 52.89 & 133.35 & 77.59 & 51.45 & 71.55 & 117.63 & 90.96 & 60.21 & 27.65 \\
\hline $1001-1100$ & 33.42 & 40.63 & 90.65 & 50.80 & 42.81 & 55.95 & 99.99 & 71.76 & 49.07 & 23.81 \\
\hline $1101-1200$ & 23.75 & 32.88 & 73.88 & 40.05 & 28.43 & 45.82 & 85.46 & 60.67 & 42.10 & 21.07 \\
\hline $1201-1300$ & 16.78 & 18.24 & 43.24 & 25.77 & 19.99 & 34.99 & 58.94 & 42.55 & 29.09 & 12.82 \\
\hline $1301-1400$ & 9.2794 & 7.6585 & 18.172 & 11.019 & 7.5395 & 16.001 & 37.356 & 24.358 & 12.923 & 4.4018 \\
\hline $1401-1500$ & 3.5737 & 2.6544 & 6.0272 & 3.2449 & 2.7883 & 6.1185 & 17.5458 & 12.0178 & 5.2418 & 1.6681 \\
\hline $1501-1600$ & 0.3992 & 0.8608 & 1.5145 & 0.8932 & 1.0255 & 2.5201 & 9.0722 & 5.5067 & 2.4727 & 0.6862 \\
\hline $1601-1700$ & 0.0135 & 0.0759 & 0.2680 & 0.0948 & 0.3683 & 0.7341 & 2.2975 & 0.6502 & 0.4361 & 0.0519 \\
\hline $1701-1800$ & 0.0285 & 0.0375 & 0.0331 & 0.0154 & 0.0176 & 0.3459 & 0.8394 & 0.3767 & 0.2623 & 0.0397 \\
\hline 1801-1900 & 0.0000 & 0.0000 & 0.0000 & 0.0000 & 0.0000 & 0.2308 & 0.4312 & 0.1799 & 0.1561 & 0.0000 \\
\hline $1901-2000$ & 0.0000 & 0.0000 & 0.0000 & 0.0000 & 0.0000 & 0.0024 & 0.1210 & 0.0242 & 0.0024 & 0.0000 \\
\hline
\end{tabular}

Note: $N^{1}, N^{2}$ - The slope exposition identifies the direction the downhill slope faces. The values of each cell in the output raster indicate the compass direction the surface faces at that location. It is measured clockwise in degrees from 0 (due north $-N^{1}$ ) to 360 (again due north $-N^{2}$ ), coming full circle. Flat areas having no downslope direction are given a value of -1 . Source/Vir: Own survey. 
Figure 8: Slopes exposition in the Una River basin. Slika 8: Ekspozicija pobočij v porečju Une.

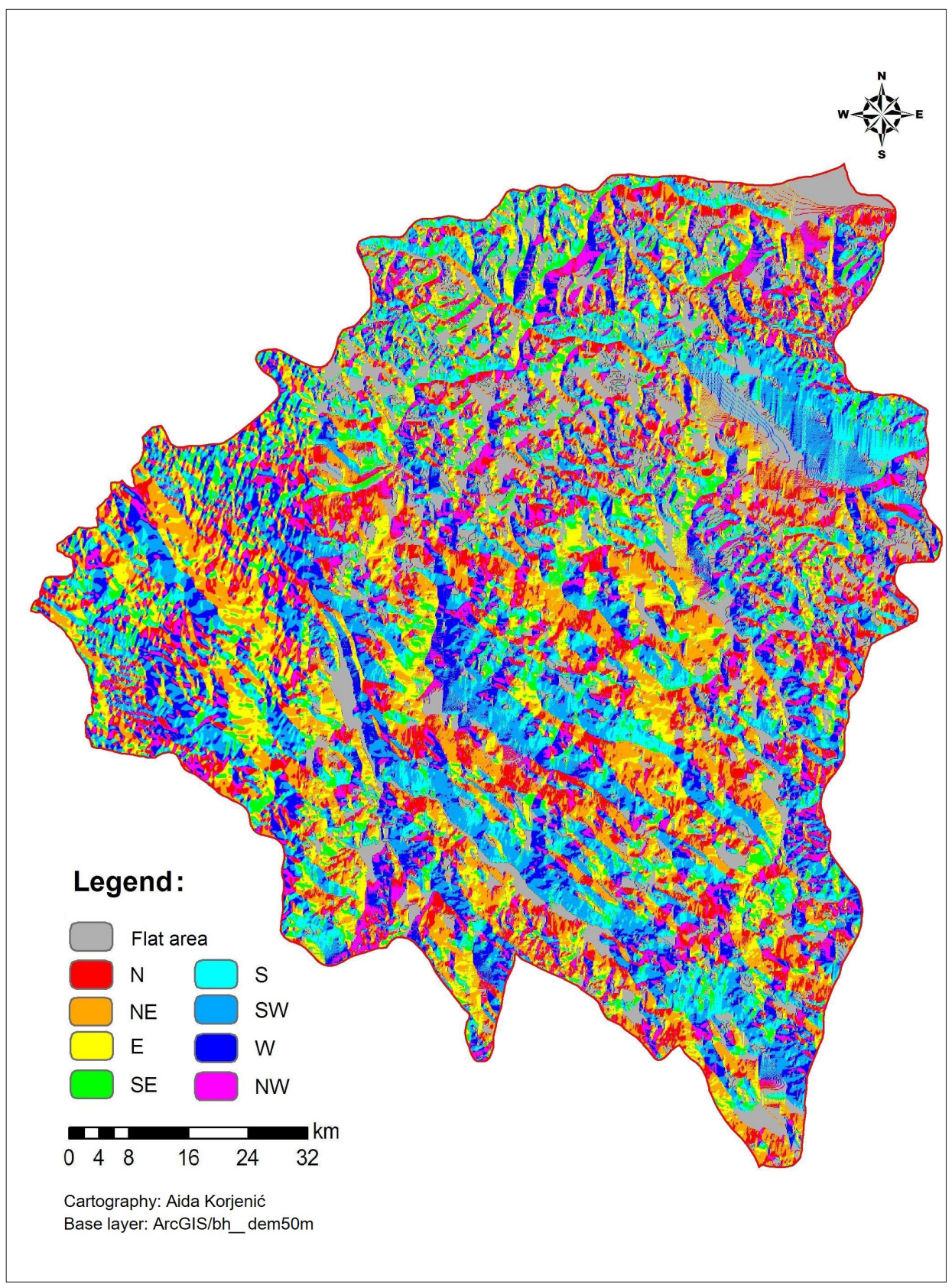




\section{CONCLUSIONS}

Analyzed parameters (hypsometry, vertical dissection, slope inclination and relief exposition) in Una River basin (Bosnia and Herzegovina) are expression of morphostructural and morphogenetic relief characteristics, and they serve as indicators of shapes and recent processes in relief. Working in the ArcGIS program, a database has been formed based on grid system, what gives a possibility of geospatial data overlapping, their correlation analysis, usage and implementation.

According to the categorization of slopes from the aspect of their suitability for agrarian exploitation and exploitation in construction (Bognar, 1990, 1992), a total of 54\% of the Una River basin is considered to be very favorable for mentioned purposes and these areas include alluvial plains and river valleys, river terraces and fields in karst. Terrains with slopes $6-15^{\circ}$, which are defined as favorable with certain measures of arrangement, comprise about $34 \%$ of the Una River basin, which relates mainly to the foothill slopes and the pediments. The most suitable areas from the aspect of agricultural activities mostly match those areas specified as the most suitable for the construction, and in that respect there might be a certain spatial conflict.

The results obtained by the quantitative geomorphological analysis in the Una River basin, have a wide useful value and they are unavoidable in procedure of determining the intensity of erosive processes, protection and improvement of spatial and living environment. Besides, they can be applied at resolving water management problems, drafting spatial plans, and planning other economic activities.

\section{References}

Bočić, N. P., 2010. Geomorfološka obilježja Slunjske zaravni. Hrvatski geografski glasnik, 72, 2, pp. 5-23.

Bognar, A., 1990. Geomorfološke i inženjersko-geomorfološke osobine otoka Hvara i ekološko vrednovanje reljefa.Geografski glasnik, 25, pp. 49-65.

Bognar, A., 1992. Inženjerskogeomorfološko kartiranje. Acta geographica Croatica, 27, pp. 173-185.

Bognar, A., 1999. Geomorfološka regionalizacija Hrvatske. Acta geographica Croatica, 34, 1, pp. 7-26.

Čičić, S., 2002. Geološka karta Bosne i Hercegovine. R 1:300.000. Sarajevo, Institut za geologiju Građevinskog fakulteta u Sarajevu.

Dikau, R., Brabb, E. E., Mark, R. M., 1991. Landform classification of New Mexico by computer. Open-File Report 91-634. Washington, U.S. Dept. of the Interior, U.S. Geological Survey, pp. 1-16.

Dobos, E., Daroussin, J., Montanarella, L., 2010. A quantitative procedure for building physiographic units supporting a global SOTER database. Hungarian Geographical Bulletin 59, 2, pp. 181-205.

Gams, I., 1981. Uputstvo za izradu pregledne geomorfološke karte SFRJ u razmeru 1:500.000. Beograd, Geografski institut „Jovan Cvijić“،, pp. 1-74. 
Horton, R. E., 1945. Erosional development of streams and their drainage basins. Bulletin of the Geological Society of America, 56, pp. 275-370.

Korjenić, A., 2014. Izohijetni i evapotranspiracijski elementi u režimu Une. Acta geographica Bosniae et Herzegovinae, 1, 1, pp. 114-123.

Marković, M. P., 2003. Geomorfologija. Beograd, Rudarsko - geološki fakultet, 189 pp.

Moore, I. D., Grayson, R. B., Ladson, A. R., 1991. Digital terrain modelling: a review of hydrological, geomorphological, and biological application. Hydrological Processes 5, pp. 3-30.

Pareta, K., Pareta, U., 2012. Quantitative Geomorphological Analysis of a Watershed of Ravi River Basin, H.P. India. International Journal of Remote Sensing and GIS, 1, 1, pp. 47-62.

Pavlopoulos, K., Evelpidou, N., Vassilopoulos, A., 2009. Mapping Geomorphological Environments. Berlin, Springer-Verlag, pp. 24-36.

Penck, A., 1894. Morphologie der Erdoberflache. Sttutgart, J. Engelhorn, 695 pp.

Pike, R. J., 1995. Geomorphometry - process, practice, and prospect. In: Pike, R. J., Dikau, R. (ed.). Advances in Geomorphometry - Proceedings of the Walter F. Wood Memorial Symposium. Zeitschrift fur Geomorphologie/Supplement, pp. 221-238.

Rao, D. P., 2002. Remote sensing application in geomorphology. Tropical Ecology, 43, 1, pp. 49-59.

Shrivastava, P. K., Bhattacharya, A. K., 2000. Delineation of groundwater potential zones in a hard rock terrain of Bargarh district, Orissa - using IRS data. Journal Indian Society of Remote Sensing, 28, 2\&3, pp. 129-140.

Spahić, M., 2002. Opća klimatologija. Sarajevo, Geografsko društvo Federacije Bosne i Hercegovine, $32 \mathrm{pp}$.

Sretenović, L. B., 1971. Kartografski metod proučavanja ekspozicija površine reljefa za potrebe prostornog planiranja. U: Bukurov, B. (ed.). Zbornik radova Geografskog instituta Prirodno-matematičkog fakulteta. sv. XVIII. Beograd, Geografski institut Prirodno-matematičkog fakulteta, pp. 105-121.

Temimović, E., 2014. Osnove reljefne strukture u slivu Sane. Acta geographica Bosniae et Herzegovinae, 1, 1, pp. 83-95.

Terrain analysis: principles and applications. 2000. Wilson, J. P., Gallant, J. C. (ed.). New Jersey, John Wiley \& Sons, 520 pp.

Trobec, T., 2016. Spatio-temporal distribution of flash floods in Slovenia. Dela, 46, pp. 21-39. DOI: 10.4312/dela.46.1.5-39. 


\section{UPORABA GEOGRAFSKEGA INFORMACIJSKEGA SISTEMA V KVANTITATIVNI GEOMORFOLOŠKI ANALIZI POREČJA UNE (BOSNA IN HERCEGOVINA)}

\section{Povzetek}

Analizirani parametri (hipsometrija, vertikalna razčlenjenost, naklon in ekspozicija pobočij) v porečju Une (Bosna in Hercegovina) so izraz morfostrukturnih in morfogenetskih značilnosti reliefa in služijo kot kazalci oblik in recentnih procesov. S programom ArcGIS smo oblikovali bazo podatkov, ki temelji na mrežnem sistemu, kar omogoča možnost prekrivanja geoprostorskih podatkov, njihove korelacijske analize in uporabnost za širšo družbo.

Kategorizacija pobočij glede njihove primernosti za kmetijstvo in gradnjo (Bognar, 1990, 1992) je pokazala, da je 54 \% porečja Une zelo primernega za ta namen. Pretežno gre za aluvialne ravnine, rečne doline, rečne terase in kraška polja. Površine z naklonom $6-15^{\circ}$ (34\% porečja) pa zahtevajo določene prilagoditve. Zaradi prekrivanja območij lahko pričakujemo prostorske konflikte.

Rezultati, pridobljeni s kvantitativno geomorfološko analizo v porečju Une, imajo široko uporabno vrednost in so nujni v procesu določanja intenzivnosti erozijskih procesov, varstva okolja in izboljšanja življenjskega okolja. Med drugim se ta metoda lahko uporablja pri reševanju problemov upravljanja z vodami, izdelavi prostorskih načrtov in načrtovanju drugih gospodarskih dejavnosti. 